\title{
技術論文*
}

\section{地球化学的手法と数値解析を用いた埼玉県狭山市の 飲料工場で使用する地下水起源の判別}

\author{
富山 钅吾 $^{\circledR 1}$, 上田 晃 $^{2}$, 北井亜希子 ${ }^{1}$, 葵 守 - ${ }^{3}$
}

\begin{abstract}
食品原材料となる地下水の品質管理の問題が起きており, 地下水の起源について水質特徵などの科学的根 拠に基づいて判別する技術が必要とされている，本研究は，埼玉県狭山市にある株式会社フードケミファ新 埼玉工場の井戸で採水している地下水と周辺河川水を対象に, 水素・酸素安定同位体比等の地球化学的手法 と 3 次元数值モデルによる地下水流動解析を用いて地下水の起源や流れを予測した. 地下水の水質は関東平 野西縁辺部の河川水と同様の重炭酸カルシウム型であり, 河川水と比較して $\mathrm{Na}^{+}$と $\mathrm{HCO}_{3}{ }^{-}$に富む傾向にあ る. 水素・酸素同位体比から，地下水の起源は入間川上流等の平野縁辺の河川にあることが推定される. 数 値モデルによる地下水流動解析では入間川上流域から新埼玉工場に向かう地下水の流れが予測され，主要 陽・陰イオン濃度や水素・酸素安定同位体比から推定される地下水流動と整合的である. 地球化学的手法と 数值解析により得られた結果は従来の知見と矛盾せず, 地下水起源の判別法としての可能性が示唆された.
\end{abstract}

\section{1 緒言}

昨今，不当表示防止法違反や水質管理によるシアン化物 污染など，地下水を対象とした食の安全にかかわる問題が 多く取り上げられている．地下水は適切な品質管理を行う ことで低コストかつ持続的な生産に寄与することのできる 天然資源であり，その起源や水質特性を明らかにすること は極めて重要な研究課題である. 地下水に先んじて社会問 題化している食品の産地偽装については, DNA 解析や無 機微量元素分析, 軽元素安定同位体比分析による産地判別 技術の開発が進められている ${ }^{1) 3)}$ ．地下水についても，我 が国と欧州の容器入り飲料水ラベルに表示されている主要 溶存成分值から地下水水質と地質との関連を論じた事例 ${ }^{4)}$ や飲料水としての水道水質の評価研究 ${ }^{5)}$, 地下水と河川水 との関連の研究 6 ( 保の必要性の観点から農業用水として用いることができる 地下水資源量の将来予測 ${ }^{7)}$ や生活用水としての水質評価 ${ }^{8)}$ などが研究されている.しかしながら，品質管理の観点に よる地下水起源の研究は，十分に行われているとは言えな い状況にある。

鉱工業分野の一つである休廃止鉱山の管理では，坑道内

\footnotetext{
*年間特集「水」

1 三菱マテリアルテクノ株式会社 : 330-0835 埼玉県さいたま市 大宮区北袋町 1-297

2 富山大学理学部生物圈環境学科 : 930-8555 富山県富山市五福 3190

${ }^{3}$ 株式会社フードケミファ新埼玉工場 : 350-1331 埼玉県狭山市 新狭山 1-5-15
}

で湧出する重金属を含む地下水の処理に年間約 30 億円に 上る費用が発生しておりり ${ }^{9)}$, 水量の低減や水質改善などの 対策が求められている. このような地下水の対策検討に当 たって, 主要陽・陰イオン濃度, 水素・酸素安定同位体比 を用いた地球科学的解析や衛星画像解析を応用した数值シ ミュレーションなど複数の手法を用いた研究が進められ,

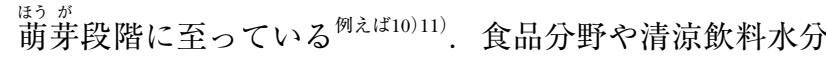
野に打いて安全と信頼を確保する観点から地下水の起源を 明らかにするには，休廃止鉱山の管理と同様に原理の異な る複数手法の重㸚合わせが有効と考元られる.

本研究では，埼玉県狭山市にあるフードケミファ新埼玉 工場（以下，新埼玉工場）の井戸で採水している地下水を 対象に, 水素・酸素安定同位体及び主要な溶存イオン濃度 や 3 次元数值モデルを用いた地下水シミュレーションによ り起源の推定を試みた。更に，リスク管理手法の検討を目 的として地下水モニタリングを行った，その結果を報告す る.

\section{2 測 定}

\section{$2 \cdot 1$ 試料採水}

採水地点を Fig. 1 に示す. 新埼玉工場は関東平野の西部, 埼玉県狭山市に位置しており, 北の入間川と南の不老川に 挟まれた場所にある. 新埼玉工場では深度 $200 \mathrm{~m}$ の井戸か ら地下水を汲み上げ，豆乳等の原材料として用いている. 狭山市周辺の地質は古多摩川や古入間川による扇状地堆積 物からなり, 表層に分布する関東ローム層の下位には優勢 な砂磅層が発達している.この砂磉層は地下水を豊富に含 


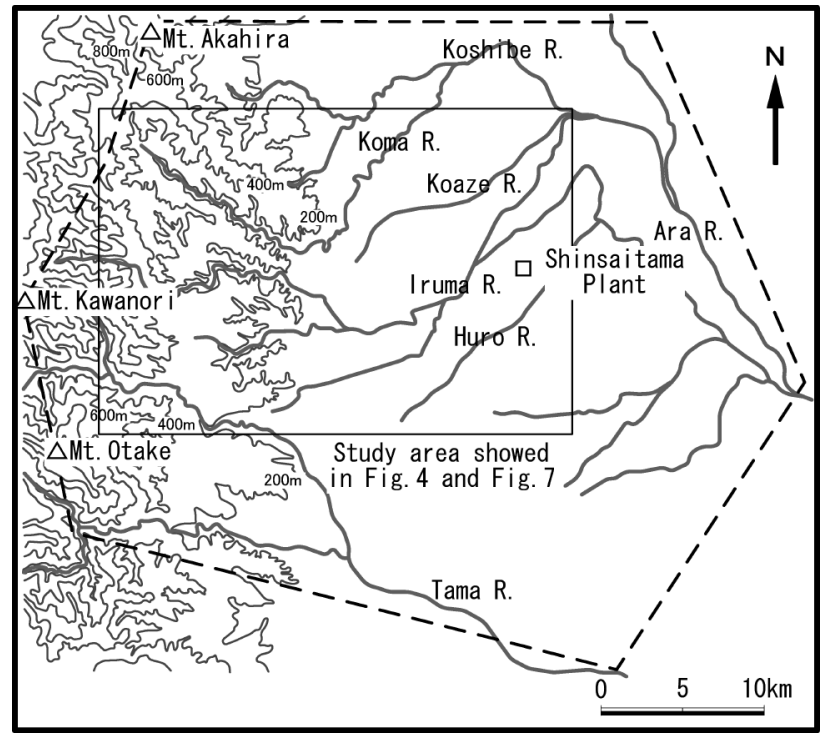

Fig. 1 Study area by applying geochemical method and the area of simulation model

The solid lines represent the area of numerical simulation

む帯水層の役割を果しており，新埼玉工場で使用している 地下水の供給源となっている (Fig. 2).

地下水の採水は, 2009 年 1 月 22 日から 12 月 17 日の 1 年間にわたり月 1 回の頻度で行った. 採水に先立ち, 井戸 口元の採水用ドレンノズルから $200 \mathrm{~L}$ 程度の予備採水をし た. 採水後, 直ちに水温, $\mathrm{pH}$, 電気伝導率 (EC) 及び酸 化還元電位（ORP）を測定し, あらかじめ酸洗浄し試料水 で共洗いした $100 \mathrm{~mL}$ のポリエチレン瓶 2 本に移し, 分析 所へ持ち帰った. また, 地下水との水質対比を目的として 2009 年 4 月 30 日 5 月 1 日に上流域 $30 \mathrm{~km}$ 範囲内の河川 水 30 試料（R-1〜 R-30）を採水した. 採水時, 地下水と同 様に水質等を測定した. なお, $\mathrm{pH}$ は新電元社の KS701を, 電気伝導率及び水温は HORIBA 社の B-173 を, 酸化還元電 位は TOA 社の RM-12P をそれぞれ測定に用いた。

\section{$2 \cdot 2$ 前処理及び測定}

水試料の分析項目と方法は次のとおりである. $\mathrm{HCO}_{3}{ }^{-}$は $\mathrm{M}$-アルカリ度として算出し, $\mathrm{HCO}_{3}{ }^{-}$濃度に換算した. その 際, M-アルカリ度は $0.01 \mathrm{M}\left(\mathrm{mol} \mathrm{L}^{-1}\right)$ の塩酸溶液で滴定 した。主要陽・陰イオンである $\mathrm{Na}^{+}, \mathrm{K}^{+}, \mathrm{Ca}^{2+}, \mathrm{Mg}^{2+}$, $\mathrm{Cl}^{-}, \mathrm{SO}_{4}{ }^{2-}, \mathrm{NO}_{3}{ }^{-}$の測定には, イオンクロマトグラフ (DIONEX 製) を用いた. 中性付近の水, すなわち $\mathrm{pH}$ $5 \sim 9$ の範囲にあって $\mathrm{H}^{+}$又は $\mathrm{OH}^{-}$の濃度が極めて小さい 水では, 当量濃度 $\left(\mathrm{meq} \mathrm{L} \mathrm{L}^{-1}\right)$ で表された陽・陰イオンの 合計はほぼ一致しなければならない。 そこで, 含有量濃度 $\left(\mathrm{mg} \mathrm{L}^{-1}\right)$ から当量濃度 $\left(\mathrm{meq} \mathrm{L} \mathrm{L}^{-1}\right)$ への換算によって得ら れる陽イオン濃度合計 $(\Sigma C)$ と㓌イオン濃度合計 $(\Sigma I)$ の

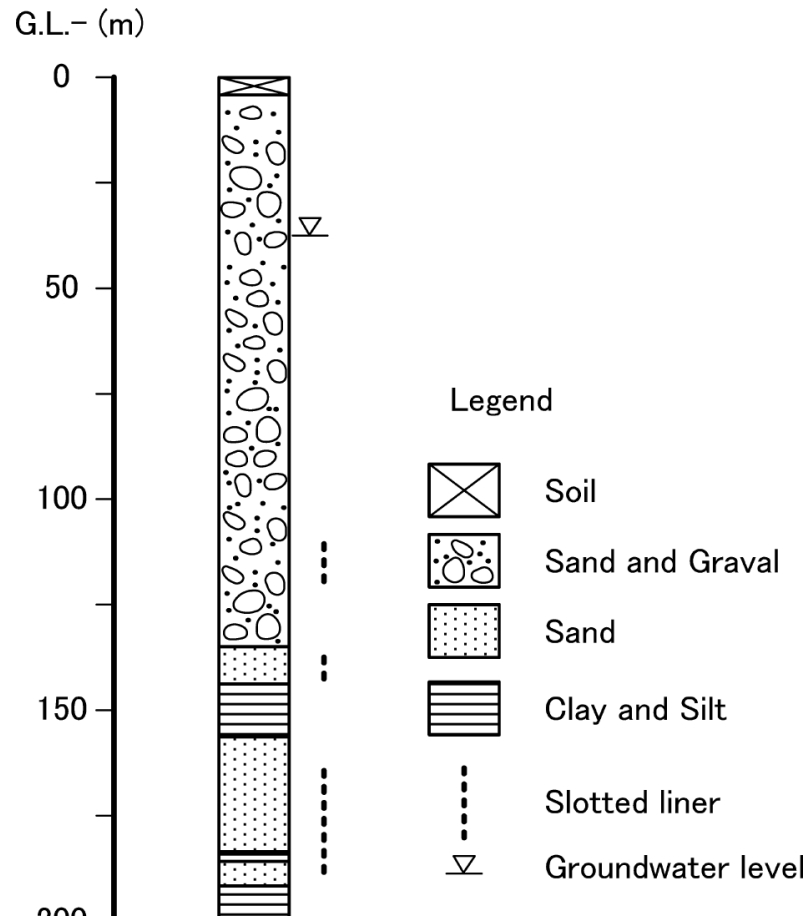

Fig. 2 Boring $\log$

バランスにより，測定精度の管理を行った． $\Sigma I$ が $3.0 \mathrm{meq}$

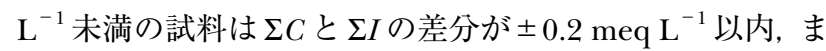
た $\Sigma I$ が $3.0 \mathrm{meq} \mathrm{L}^{-1}$ 以上の試料については次式, $(\Sigma C-$ $\Sigma I) /(\Sigma C+\Sigma I) \times 100$ によって求められるチャージバラン スが $\pm 2 \%$ 以内に収まることを基準とした ${ }^{12)}$. 本研究にお ける分析試料はすべて，上記基準を満たしている.

水素同位体比に関しては水素ガス製造法及び水素同位体 分析法 ${ }^{13)}$, 酸素同位体比に関しては二酸化炭素平衡法を使っ て前処理を行った後, 質量分析計 (Micromass 製 Optima) を用いて測定した. 水素・酸素安定同位体比は, 標準試料 からの千分率偏差（パーミル，\%) で表した。これらは次 式, $\delta \mathrm{X}=\left(R_{\text {陚料 }} / R_{\text {標準 }}-1\right) \times 1000$ によって $\delta$ 值として表記 した. ここでXは水素, 酸素に対してそれぞれ $\delta \mathrm{D}$ 及び $\delta^{18} \mathrm{O}$ を表し， $R$ はそれぞれの元素の同位体比 $\mathrm{D} / \mathrm{H},{ }^{18} \mathrm{O} /{ }^{16} \mathrm{O}$ で ある. 測定にはあらかじめ標準平均海水 (SMOW) に対す る $\delta$ 值を求めておいたイオン交換水をスタンダードとして 用い，測定值を SMOW 標準の $\delta$ 值に換算した。測定精度 は $\delta \mathrm{D}$ で $\pm 1.0 \%, \quad \delta^{18} \mathrm{O}$ で $\pm 0.1 \%$ である.

\section{3 地球化学的手法による結果と考察}

\section{$3 \cdot 1$ 水質の特徵}

地下水の採水時水質測定と室内分析結果を Table 1 に, シュティフダイアグラムを Fig. 3 にそれぞれ示す. また, 河川水のシュティフダイアグラムを Fig. 4 に示す.

Fig. 3 のシュティフダイアグラムから陽イオンは $\mathrm{Ca}^{2+}$, また陰イオンは $\mathrm{HCO}_{3}{ }^{-}$に富む $\mathrm{Ca}-\mathrm{HCO}_{3}$ 型の水質を示すこ 
Table 1 Chemical composition and stable isotope ratio of groundwater

\begin{tabular}{|c|c|c|c|c|c|c|c|c|c|c|c|c|c|c|}
\hline \multirow{2}{*}{ Sampling date } & \multirow{2}{*}{$\mathrm{pH}$} & \multirow{2}{*}{$\begin{array}{l}\text { Tem, } \\
{ }^{\circ} \mathrm{C}\end{array}$} & \multirow{2}{*}{$\begin{array}{c}\mathrm{ORP} / \\
\mathrm{mV}\end{array}$} & \multirow{2}{*}{$\begin{array}{c}\mathrm{EC} / \\
\mathrm{mS} \mathrm{m}^{-1}\end{array}$} & \multicolumn{8}{|c|}{ Chemical composition $/ \mathrm{mg} \mathrm{L}^{-1}$} & \multicolumn{2}{|c|}{$\begin{array}{l}\text { Stable isotope } \\
\text { ratio, \%o }\end{array}$} \\
\hline & & & & & $\mathrm{Na}^{+}$ & $\mathrm{K}^{+}$ & $\mathrm{Ca}^{2+}$ & $\mathrm{Mg}^{2+}$ & $\mathrm{Cl}^{-}$ & $\mathrm{HCO}_{3}{ }^{-}$ & $\mathrm{SO}_{4}{ }^{2-}$ & $\mathrm{NO}_{3}{ }^{-}$ & $\delta \mathrm{D}$ & $\delta^{18} \mathrm{O}$ \\
\hline 22 $2^{\text {nd }}$ January, 2009 & 7.7 & 11.7 & 338 & 11.9 & 11 & 2.1 & 11 & 3.6 & 5.6 & 68 & 2.4 & 0.38 & -58.5 & -8.9 \\
\hline $19^{\text {th }}$ February, 2009 & 7.7 & 16.0 & 254 & 13.2 & 11 & 2.1 & 12 & 3.7 & 5.6 & 68 & 2.5 & 0.81 & -58.2 & -8.9 \\
\hline $19^{\text {th }}$ March, 2009 & 7.4 & 19.0 & 235 & 12.8 & 10 & 2.1 & 11 & 3.6 & 5.7 & 70 & 2.5 & 0.80 & -57.5 & -9.0 \\
\hline $16^{\text {th }}$ April, 2009 & 7.7 & 18.9 & 244 & 14.4 & 11 & 2.1 & 11 & 3.6 & 5.8 & 69 & 2.6 & 0.47 & -56.1 & -9.1 \\
\hline $21^{\text {st }}$ May, 2009 & 7.1 & 20.0 & 220 & 13.1 & 10 & 2.1 & 11 & 3.6 & 6.3 & 67 & 2.5 & 0.73 & -58.1 & -9.1 \\
\hline $18^{\text {th }}$ June, 2009 & 7.7 & 18.0 & 227 & 12.7 & 10 & 2.1 & 11 & 3.6 & 5.9 & 66 & 3.2 & 0.44 & -58.1 & -9.0 \\
\hline $17^{\text {th }}$ July, 2009 & 7.6 & 21.0 & 215 & 12.6 & 10 & 2.0 & 11 & 3.6 & 5.2 & 67 & 1.9 & 0.68 & -57.6 & -9.0 \\
\hline $20^{\text {th }}$ August, 2009 & 7.7 & 21.0 & 200 & 13.0 & 10 & 2.1 & 11 & 3.6 & 5.2 & 68 & 2.0 & 0.90 & -56.9 & -9.0 \\
\hline $17^{\text {th }}$ September, 2009 & 7.5 & 23.0 & 142 & 10.0 & 11 & 2.0 & 11 & 3.7 & 5.1 & 66 & 2.0 & 0.36 & -58.8 & -9.1 \\
\hline $15^{\text {th }}$ October, 2009 & 7.7 & 19.0 & 141 & 14.8 & 10 & 2.0 & 11 & 3.6 & 5.5 & 66 & 2.3 & 0.49 & -58.2 & -9.1 \\
\hline $19^{\text {th }}$ November, 2009 & 7.4 & 16.0 & 206 & 10.1 & 11 & 2.1 & 11 & 3.6 & 5.0 & 67 & 2.5 & 0.64 & -56.9 & -9.0 \\
\hline $17^{\text {th }}$ December, 2009 & 7.3 & 16.0 & 120 & 11.0 & 10 & 2.0 & 11 & 3.6 & 5.2 & 67 & 1.8 & 0.97 & -57.4 & -9.1 \\
\hline
\end{tabular}

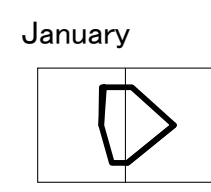

July

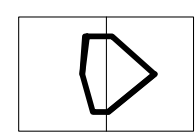

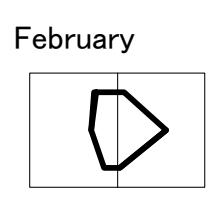

August

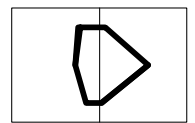

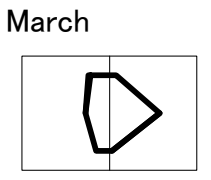

September

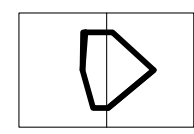

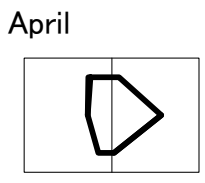

October

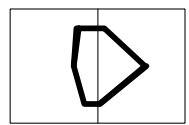

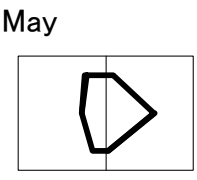

June
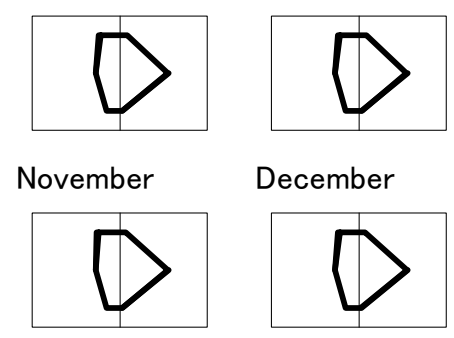

December

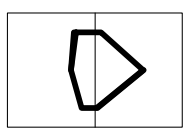

meq $\mathrm{L}^{-1}$

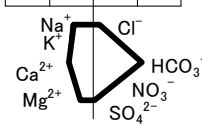

Fig. 3 Stiff-diagrams for groundwater

とが分かる. また, シュティフダイアグラムの形が年間を 通じてほとんど変わらず，地下水中の主要陽・陰イオンの 濃度が季節によらず一定であることが唯われる。

河川水のシュティフダイアグラム (Fig. 4) では地形によ りグループ分けし, 山地で採水した河川水を○, 平野縁辺 部の河川水を○, そして平野部の河川水を○で表示した. 山地及び平野縁辺部の河川水は大部分が地下水と同様の $\mathrm{Ca}-\mathrm{HCO}_{3}$ 型の水質であるが, 地下水と比較して $\mathrm{Ca}^{2+} に$ 富 み, $\mathrm{Na}^{+}$に乏しい傾向がある。 一方平野部の河川水は $\mathrm{Ca}-\mathrm{HCO}_{3}$ 型のほかに $\mathrm{Na}-\mathrm{Cl}$ 型や $\mathrm{Ca}-\mathrm{Cl}$ 型, $\mathrm{Ca}-\mathrm{SO}_{4}$ 型といっ た多様な水質を呈する. また, 山地及び平野縁辺部の河川 水と比較して, $\mathrm{NO}_{3}{ }^{-}$に富む.

地下水及び河川水のトリリニアダイアグラムを Fig. 5 に 示す. Fig. 5 では, 地下水と山地の河川水は我が国の循環 性地下水の水質である I 型：重炭酸カルシウム型 ${ }^{14)}$ の領域 に分布するが, 平野縁辺部と平野部の河川水は $\mathrm{I}$ 型から $\mathrm{V}$ 型：中間型 ${ }^{14)}$ の領域にかけて分布し, 平野部の河川水は更 にIV 型: 非重炭酸ナトリウム型 ${ }^{14)}$ の領域に及ぶ. 地下水は 山地の河川水と同じ I 型に該当するが, より $\mathrm{Na}^{+}$と $\mathrm{HCO}_{3}{ }^{-}$
に富む傾向にある．

\section{$3 \cdot 2$ 水素・酸素安定同位体比}

地下水の起源を判別する手法として, 地下水中に含まれ る水素・酸素安定同位体を天然トレーサーとして利用する 研究が注目されている ${ }^{15) 16)}$ 。重水素（D）及び重酸素 18 $\left({ }^{18} \mathrm{O}\right)$ は，それぞれの同位体である水素 $(\mathrm{H})$ や酸素 16 $\left({ }^{16} \mathrm{O}\right)$ と化学的には全く性質が同じであるが，物理的には 質量が違うため, 融点や沸点が異なる。このため, 蒸発時 に選択的に質量の小さな同位体から気化し，また凝結時に は質量の大きな同位体から液化する現象がみられる。この ような現象を同位体効果と呼び, 気団が海岸から内陸に移 動しながら雨を降らす場合は, 内陸ほど同位体比が低くな る (内陸効果).また, 山麓斜面では標高が高くなるほど同 位体比は低くなる (高度効果) ほか, 同一標高で比較した 場合, 風下側が風上側よりも降水の同位体比が低くなる (山除効果)。地表から地下に浸透した降水は，一定の時間 を経て再び河川や海域に流出する. その間, 地下水中の水 素・酸素安定同位体比は, 異なる起源の地下水と混合する 


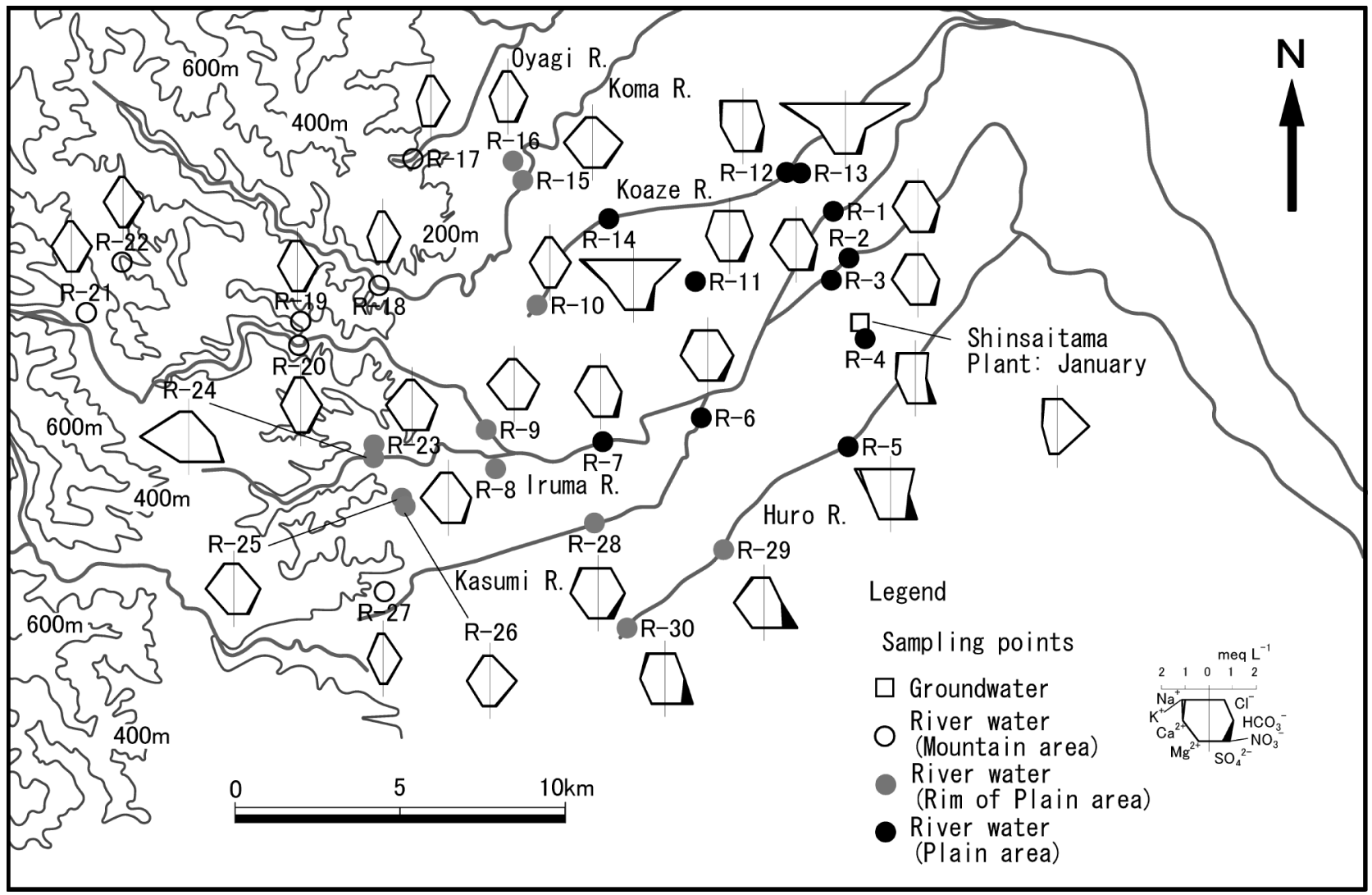

Fig. 4 Stiff-diagrams for river water

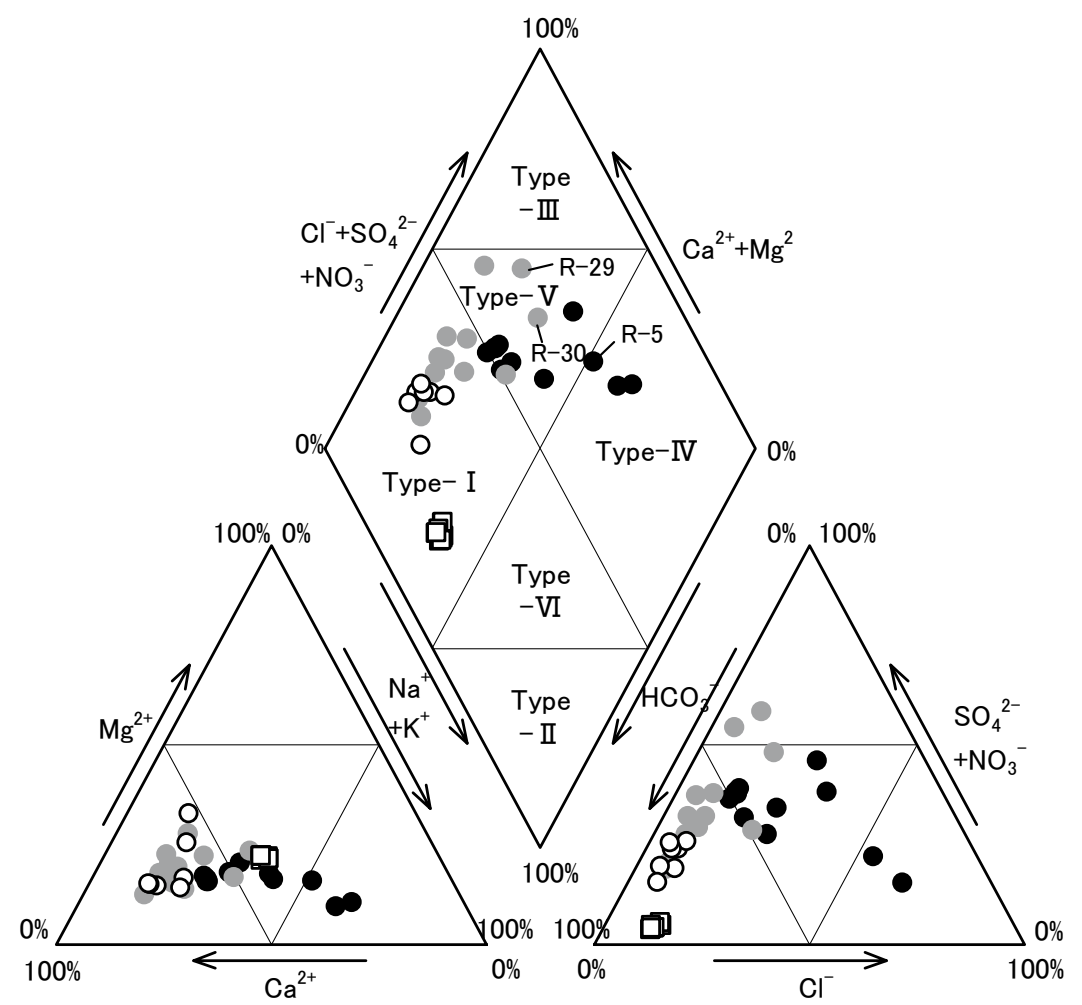

Fig. 5 Trilinear diagrams for water samples

$\bigcirc$ : River water (Mountain area), $\bigcirc$ : River water (Rim of Plain area), $\bigcirc$ : River water (Plain area), $\square$ : Groundwater 
場合を除き，地下へ浸透した際の同位体比を保持してい る。このような降水中の同位体存在比と地下水の同位体保 存性を利用し，地下水と周辺河川の水素・酸素安定同位体 比を比較検討することで, 地下水が浸透した場所（涵養

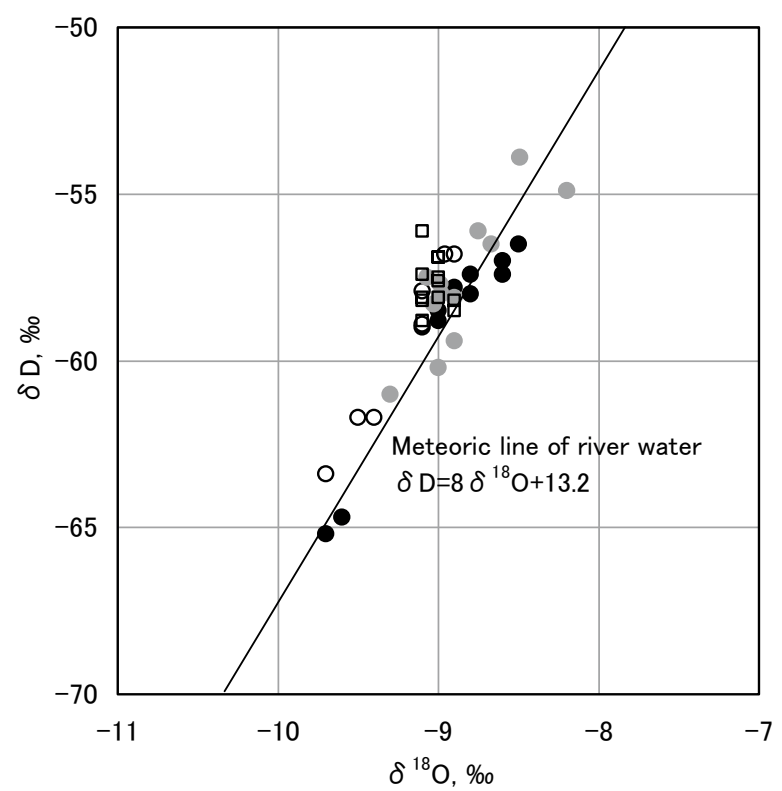

Fig. 6 Relationship between $\delta \mathrm{D}$ and $\delta^{18} \mathrm{O}$

$\bigcirc$ : River water (Mountain area), $\bigcirc$ : River water (Rim of Plain area), : River water (Plain area), $\square$ : Groundwater
域), すなわち地下水起源の判別が可能となることがある. 地下水及び河川水の水素同位体比と酸素同位体比の $\delta$ 夕゙ イアグラムを Fig. 6 に，酸素同位体比の分布を Fig. 7 にそ れぞれ示す. 河川水の安定同位体比は $\delta \mathrm{D}$ が-53.9〜 $-65.2 \%, \quad \delta^{18} \mathrm{O}$ が $-8.2 \sim-9.7 \%$ の範囲にある. 地形によ るグループごとの同位体比をみると山地では $\delta \mathrm{D}$ が -56.8 〜 $-63.4 \%$ (平均 $-59.6 \%$ ),$\delta^{18} \mathrm{O}$ が $-8.9 \sim-9.7 \%$ （平均 $-9.2 \%$ ), 平野縁辺部では $\delta \mathrm{D}$ が $-53.9 \sim-61.0 \%$ (平均 $-57.6 \%$ ),$\delta^{18} \mathrm{O}$ が $-8.2 \sim-9.3 \%$ (平均 $-8.9 \%$ ), そして 平野部では $\delta \mathrm{D}$ が- $56.5 \sim-65.2 \%$ 。平均 $-59.1 \%$ o), $\delta^{18} \mathrm{O}$ が $-8.5 \sim-9.7 \%$ 。 平均 $-9.0 \%$ o ) の範囲にある. 水素・酸 素同位体比共に山地の河川水が低い傾向にあり, 同位体の 高度効果ないしは内陸効果が窅われる. 地下水の水素・酸 素同位体比は $\delta \mathrm{D}$ が-56.1〜 - 58.8\% (平均 $-57.7 \%$ ), $\delta^{18} \mathrm{O}$ が $-8.9 \sim-9.1 \%$ （平均 $-9.0 \%$ ）の範囲にあり， $\delta$ ダイア グラム（Fig. 6）上では高麗川上流の R-16 や大谷木川上流 の R-17, 入間川上流の R-24, R-25, 霞川上流の R-27, 不老 川上流の R-29 及び R-30 に近似する。これらは R-27 が山地 の河川水であるほかはすべて平野縁辺部の河川水であり, 地下水の起源となっていることが推定される．対象とした 試料の中では, 不老川の河川水 R-4 及び R-5 が最も低い水 素同位体比を示す。これらは平野部の河川であり, 地形的 境界を越えた河川水の導水による可能性 ${ }^{17)}$ が考えられる.

Fig. 6 には水素・酸素同位体比の分布傾向を表す天水線

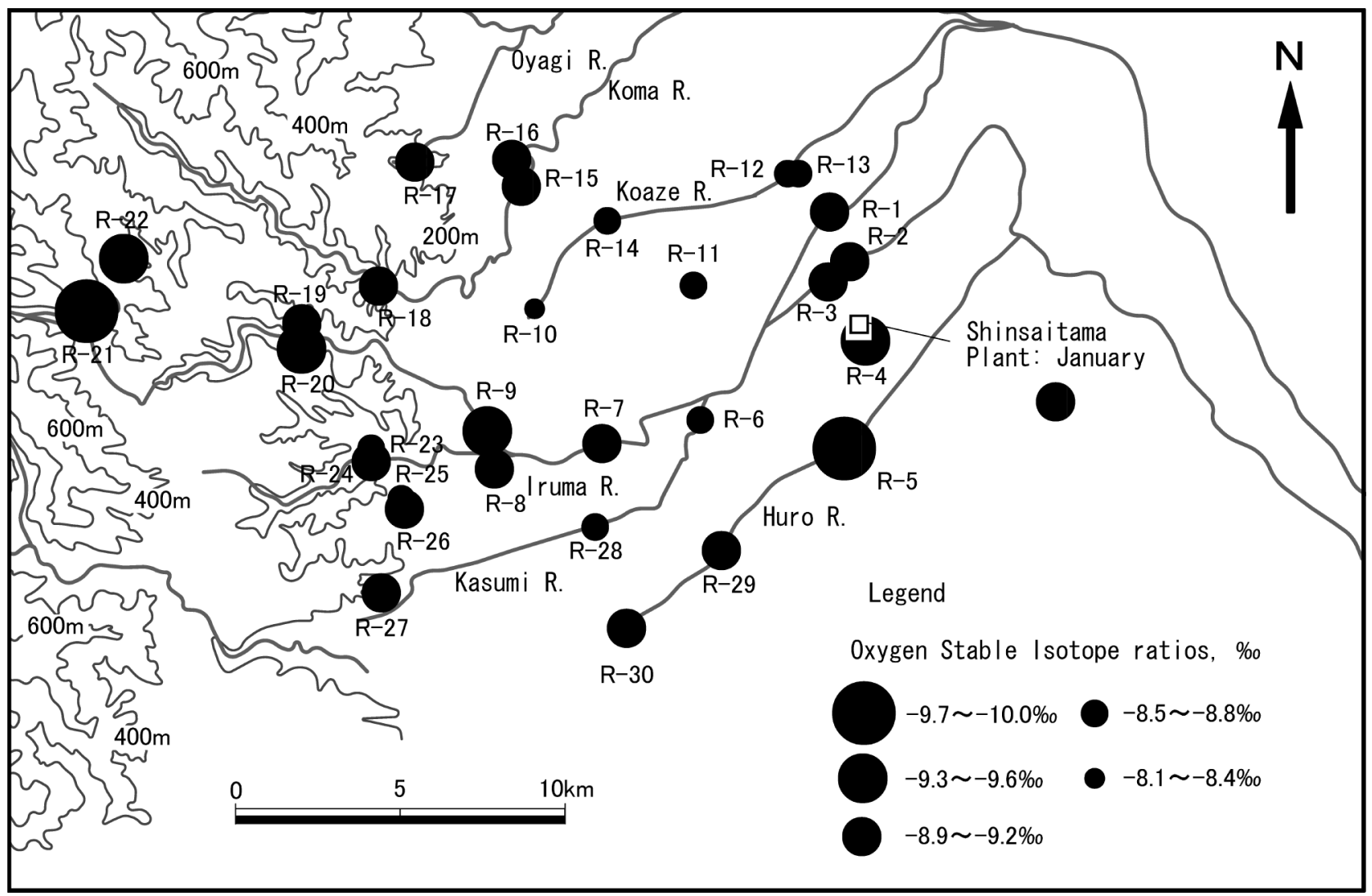

Fig. 7 Spatial distribution of oxygen stable isotope ratio 
を併記した. $\delta \mathrm{D}$ と $\delta^{18} \mathrm{O}$ の関係を傾き 8 の直線で表したとき の $d=\delta \mathrm{D}-8 \times \delta^{18} \mathrm{O}$ により定義される定数 $d$ (Deuterium excess $d$, 以下 $d$ 值という) は関東平野全域では 7〜19の 範囲に入り, 山地で比較的高く, 平野で比較的低いことが 知られている ${ }^{17)}$. 本研究による河川水の平均 $d$ 值は山地が 14.3, 平野縁辺部が 13.2, 平野が 12.6 であり, 上記した関 東平野全域の傾向と矛盾しない. 地下水の $d$ 值は 12.7 16.7 の範囲にあり (平均 14.5), 山地及び平野縁辺部の河 川水の $d$ 值に類似する.

\section{$3 \cdot 3$ 統計量解析（主成分分析）}

統計量解析は多数の変量から少数の総合特性值を抽出 し, 少数次元で解釈することでデータが持つ本質的な情報 を理解するために用いられる手法である．水質調査では複 数の成分の分析濃度が得られる. このため, 各水試料は濃 度を特性值とする多変量的存在とみなすことができ, 地下 水 . 湧水, 河川水の多数試料の水質対比 ${ }^{18)}{ }^{19)}$ や温泉水の分

Table 2 Results on principal component analysis

\begin{tabular}{crrrr}
\hline & & Factor 1 & Factor 2 & Factor 3 \\
\hline $\mathrm{pH}$ & & 0.08 & -0.42 & -0.07 \\
Temperature & & 0.18 & -0.04 & 0.22 \\
ORP & & -0.21 & -0.03 & 0.34 \\
$\mathrm{EC}$ & & $\mathbf{0 . 3 6}$ & 0.00 & 0.08 \\
\hline & $\mathrm{Na}^{+}$ & 0.31 & 0.16 & $\mathbf{0 . 3 8}$ \\
& $\mathrm{K}^{+}$ & 0.31 & 0.16 & 0.35 \\
& $\mathrm{Ca}^{2+}$ & 0.32 & -0.12 & $-\mathbf{0 . 4 0}$ \\
Chemical & $\mathrm{Mg}^{2+}$ & 0.34 & 0.16 & 0.03 \\
composition & $\mathrm{Cl}^{-}$ & $\mathbf{0 . 3 7}$ & 0.10 & 0.27 \\
& $\mathrm{HCO}_{3}{ }^{-}$ & 0.00 & 0.37 & -0.30 \\
& $\mathrm{SO}_{4}{ }^{2-}$ & 0.34 & -0.18 & -0.33 \\
& $\mathrm{NO}_{3}{ }^{-}$ & $\mathbf{0 . 3 5}$ & -0.19 & -0.22 \\
\hline \multirow{2}{*}{ Stable isotope } & $\delta^{18} \mathrm{O}$ & 0.07 & $\mathbf{0 . 4 7}$ & -0.20 \\
& $\delta \mathrm{D}$ & -0.05 & $\mathbf{0 . 5 4}$ & -0.19 \\
\hline \multirow{2}{*}{ Rate of contribution $(\%)$} & 39.0 & 18.7 & 15.3 \\
\hline
\end{tabular}

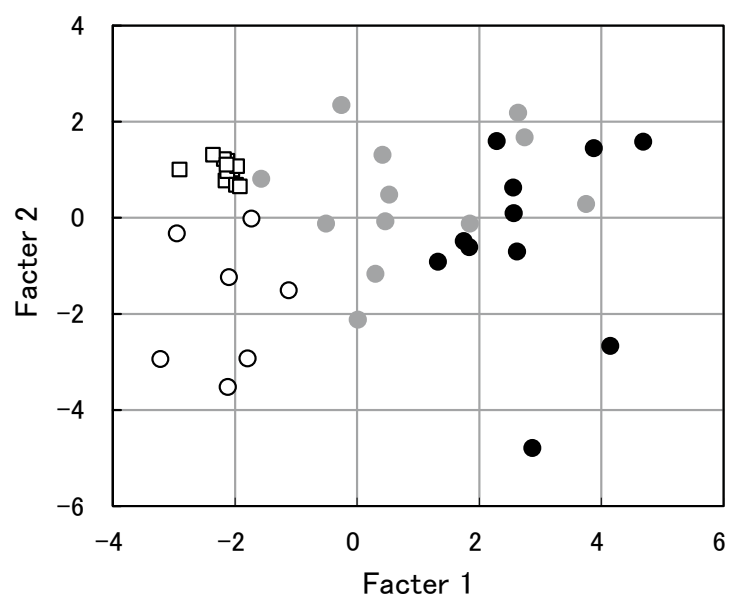

類 $^{20)}$ など, 多くの研究において適用されている. 統計量解 析には多様な手法があるが，本研究では主成分分析を適用 した．主成分分析では， $n$ 個の水質試料が $p$ 変量を座標軸 とする $p$ 次元空間に分布することを想定する．この空間に おける水質試料の分散が最大となる方向の直線を第 1 主成 分とし，次にこの第 1 主成分と直交する $p-1$ 次元空間に おける試料分布の分散が最大になる方向を第 2 主成分とす る.この過程を全分散に対する累積寄与率が $100 \%$ に近接 するまで反復する.

解析には多变量解析ソフトウエア Pirouette LE Ver.3.11

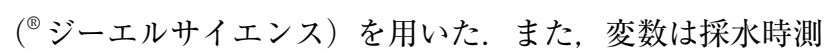
定データである水温, $\mathrm{pH}$, 電気伝導率, 酸化還元電位と室 内分析による $\mathrm{Na}^{+}, \mathrm{K}^{+}, \mathrm{Ca}^{2+}, \mathrm{Mg}^{2+}, \mathrm{Cl}^{-}, \mathrm{HCO}_{3}{ }^{-}, \mathrm{SO}_{4}{ }^{2-}$, $\mathrm{NO}_{3}{ }^{-}$濃度及び水素・酸素安定同位体比の全 14 項目とし た. 変数の規格化方法として主要陽 - 陰イオン濃度 8 項目 については常用対数により規格化し，その他採水時測定 データと水素・酸素同位体比は測定值の真数を用いた.

主成分分析により得られた第 1 主成分, 第 2 主成分及び 第 3 主成分の因子負荷量の成分行列（Table 2）では，第 1 主成分は $\mathrm{Cl}^{-}, \mathrm{NO}_{3}{ }^{-}$濃度と電気伝導率の因子負荷量が高 く, 農業用肥料や生活排水の混入など人為的な寄与を示唆 する. 第 2 主成分は水素・酸素同位体比の因子負荷量が大 きく，同位体効果を反映したものである．第 3 主成分は $\mathrm{Na}^{+}$の因子負荷量が正, また $\mathrm{Ca}^{2+}$ の因子負荷量が負の值で 大きく, 地層中に存在するスメクタイトとのイオン交換に よる $\mathrm{Ca}^{2+}$ 濃度の低下と $\mathrm{Na}^{+}$濃度の上昇 ${ }^{21}$ が一つの可能性 として考えられる. 以上の第 1 主成分から第 3 主成分の寄 与率の合計は $73 \%$ であり, 河川水と地下水の水質がこれ ら三つの要因に支配され形成されていることが分かる.

Fig. 8 に示した第 1 - 第 2 主成分及び第 1 - 第 3 主成分 の散布図では, 河川水と地下水の特徴が明確に区分でき る. 地下水は第 1 , 第 2 , 第 3 主成分の変動幅が小さく, 散

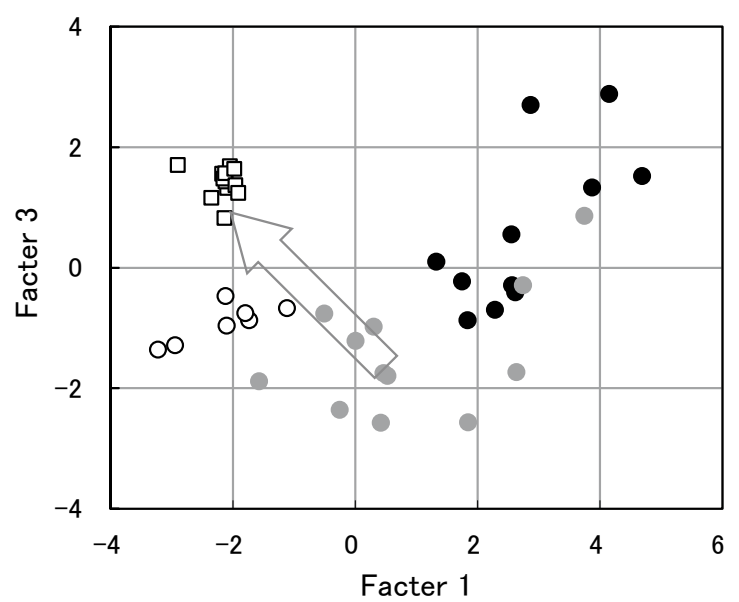

Fig. 8 Principal component scores

$\bigcirc$ : River water (Mountain area), $\bigcirc$ : River water (Rim of Plain area),

River water (Plain area), $\square$ : Groundwater 
布図上でまとまって分布するのに対し，河川水は主成分得 点のばらつきが大きい. 第 1 主成分のうち $\mathrm{NO}_{3}{ }^{-}$の起源と して, 農業用窒素肥料や畜産廃棄物あるいは生活排水中の アンモニアの硝化による人為起源のほか, 降水中の硝酸性 窒素など複数の要因が考えられている ${ }^{22)}$. 第 1 - 第 2 主成 分の散布図上では, 山地 $\rightarrow$ 平野縁辺部 $\rightarrow$ 平野部の順に第 1 主成分の得点が高くなっており, 河川下流域になるほど污 染の総負荷量が増加する状況が推察される. 狭山市周辺に おける土地利用の状況は平野縁辺部では茶畑をはじめとす る農地利用が多く, 平野部は市街地が大部分を占める ${ }^{23)}$. 窒素安定同位体比を用いた地下水の硝酸性窒素污染と土地 利用の関係に関する研究では, 農地を主とする地域の地下 水は施肥起源の $\mathrm{NO}_{3}{ }^{-}$や $\mathrm{Ca}^{2+}, \mathrm{Mg}^{2+}$ の影響によりトリリニ アダイアグラム上で III 型の領域に分布し，また低層住宅 地では生活排水起源の $\mathrm{NO}_{3}{ }^{-}$により IV 型の領域に分布する 傾向があることが示されている ${ }^{24)}$. 本研究における河川水 試料の $\mathrm{NO}_{3}{ }^{-}$濃度は $1.3 \sim 41 \mathrm{mg} \mathrm{L}^{-1}$ の範囲にあり, このう ち不老川の河川水 3 試料 (平野縁辺部の R-29, R-30 及び平 野部の R-5）では $30 \mathrm{mg} \mathrm{L}^{-1}$ を超えている. これら河川水 のトリリニアダイアグラム上での分布に着目すると, III 型 に近接するV 型の領域から VI型の領域にかけて位置し, そ の他平野部の河川水も同様の分布傾向を示す（Fig. 5). 既 存研究における知見と合わせると, 本研究における河川水 中 $\mathrm{NO}_{3}{ }^{-}$の起源として平野縁辺部では施肥が主であり, 下 流の平野部では施肥に加えて生活排水が寄与している状況 が想定される. 地下水の $\mathrm{NO}_{3}{ }^{-}$濃度は $0.36 \sim 0.97 \mathrm{mg} \mathrm{L}^{-1}$ の 範囲にあり河川水の濃度よりも低く, その要因として地中 の微生物による脱窒や植物による吸収, 又は希釈などが考 えられる.

第 2 主成分は水素・酸素同位体の同位体効果と考えら れ, 第 1 - 第 2 主成分の散布図上において河川水のばらつ きが大きいのに対し地下水は得点幅が狭く, 地下水の同位 体比の季節的な変動幅が小さいことを反映している. 第 3 主成分は地層中の粘土鉱物とのイオン交換の可能性が考え られ, 山地及び平野縁辺部の河川水と比較して地下水の得 点が高い. 一部平野部の河川水も第 3 主成分の得点が高い が, これは人間活動により排出された $\mathrm{Na}^{+}$が寄与している 可能性がある.

第 1 - 第 3 主成分散布図では地下水が平野縁辺部ないし は山地の河川水を起源とし, 地層を流動中に $\mathrm{Na}^{+}$濃度が増 加する（第 3 主成分の得点が高い領域へ移行する）ととも に, $\mathrm{NO}_{3}{ }^{-}$濃度が減少する（第 1 主成分の得点が低い領域へ 移行する）状況を矢印で表した。

\section{$3 \cdot 4$ 新埼玉工場の地下水起源}

関東平野は周囲を山地や丘陵に囲まれ, 東側は太平洋, また南側は東京湾に面する堆積盆地である。研究対象地は
関東平野の西部に位置し，周辺には古多摩川や古入間川に よる扇状地堆積物とそれを覆う関東ローム層が分布する. 扇状地堆積物は砂礫層, 砂層, 粘土〜シルト層からなり, 地下水はこのうちの砂啋層と砂層を選択的に流れている.

関東平野の地下水は, 平野周縁から平野中央へ向かうに 従い水質が変化し, 平野周辺では I 形（重炭酸カルシウム 型）であるが平野中央部ではV 型 (中間型), そして沿岸 域では IV 型 (非重炭酸ナトリウム型) の水質を呈すること が知られている ${ }^{25)}$.また，地下水温を用いた関東平野の広 域地下水流動系に関する研究では, 平野縁辺の丘陵及び台 地部で涵養され, 平野中央部及び東京湾湾岸部に流出する 地下水流動系の存在が確認されている ${ }^{26)}$.

本研究で明らかとなった水素・酸素同位体比は分析精度 を考慮すると高麗川や大谷木川，入間川，霞川及び不老川 上流の河川水に近似すると判断され, 平野縁辺部を起源と みなす既存の研究成果 ${ }^{27)}$ と矛盾しない. 地下水の水質は山 地や平野縁辺部の河川水と同様な I 型（重炭酸カルシウム 型）であるが, より $\mathrm{Na}^{+}$と $\mathrm{HCO}_{3}{ }^{-}$に富む傾向にある.こ れは地層中の粘土鉱物とのイオン交換によるものと解釈で きる. また, 地下水中の主要陽・陰イオンの濃度が年間を 通して一定であることは，季節によらず地下水の起源に大 きな変動がないことを示唆している．以上の検討結果を整 理し，地下水理概念図を作成した（Fig. 9). 概念図では, 新埼玉工場を通る東西方向の断面を表現した。概念図の基 本的な考え方を以下に示す.

(1)関東平野西部の入間川, 不老川等を流れる河川水は地下 に浸透し, 扇状地堆積物中を平野中央部へ向けて流れて いる.

(2)新埼玉工場の地下水の水質は山地や平野縁辺部の河川水 と同様な I 型（重炭酸カルシウム型）である. 河川水と 比較して, より $\mathrm{Na}^{+}$と $\mathrm{HCO}_{3}{ }^{-}$に富むことから地層中の 粘土鉱物とのイオン交換が生じている可能性がある。ま た地下水の $\mathrm{NO}_{3}{ }^{-}$濃度は河川水の濃度よりも低く, その 要因として地中の微生物による脱窒や植物による吸収, 又は希釈などが考えられる.

(3)新埼玉工場の地下水は, 水素・酸素同位体比により平野 縁辺部の河川水が起源であると推定され, 主要陽・陰イ オン濃度が年間を通して一定であることから地下水起源 に大きな季節的変動はないものと考えられる.

\section{3 次元地下水流動解析の結果と考察}

\section{$4 \cdot 1$ 数値モデル及び解析方法}

主要陽・陰イオン濃度及び水素・酸素安定同位体比から 推定した地下水理概念の妥当性評価を目的として, 3 次元 数值モデルによる地下水流動解析を行った. 数值モデルの 条件設定を Table 3 に示す. モデル化の領域は新埼玉工場 周辺を包含する東西 $47 \mathrm{~km}$, 南北 $40 \mathrm{~km}$, 地表から標高 


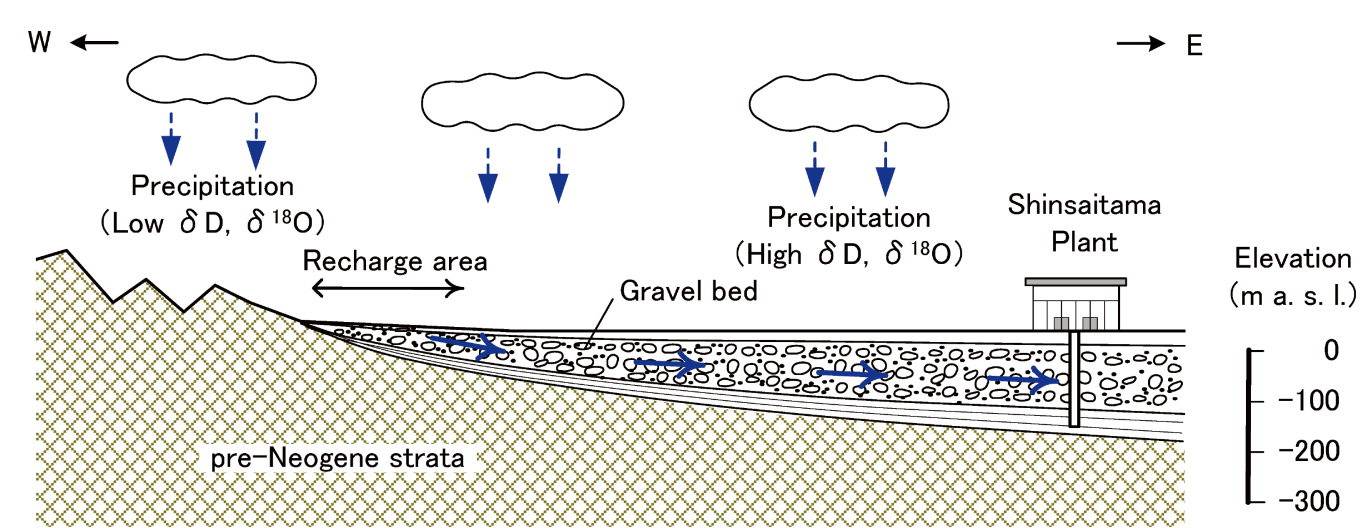

Fig. 9 Schematic vertical section showing flow direction and recharge of groundwater

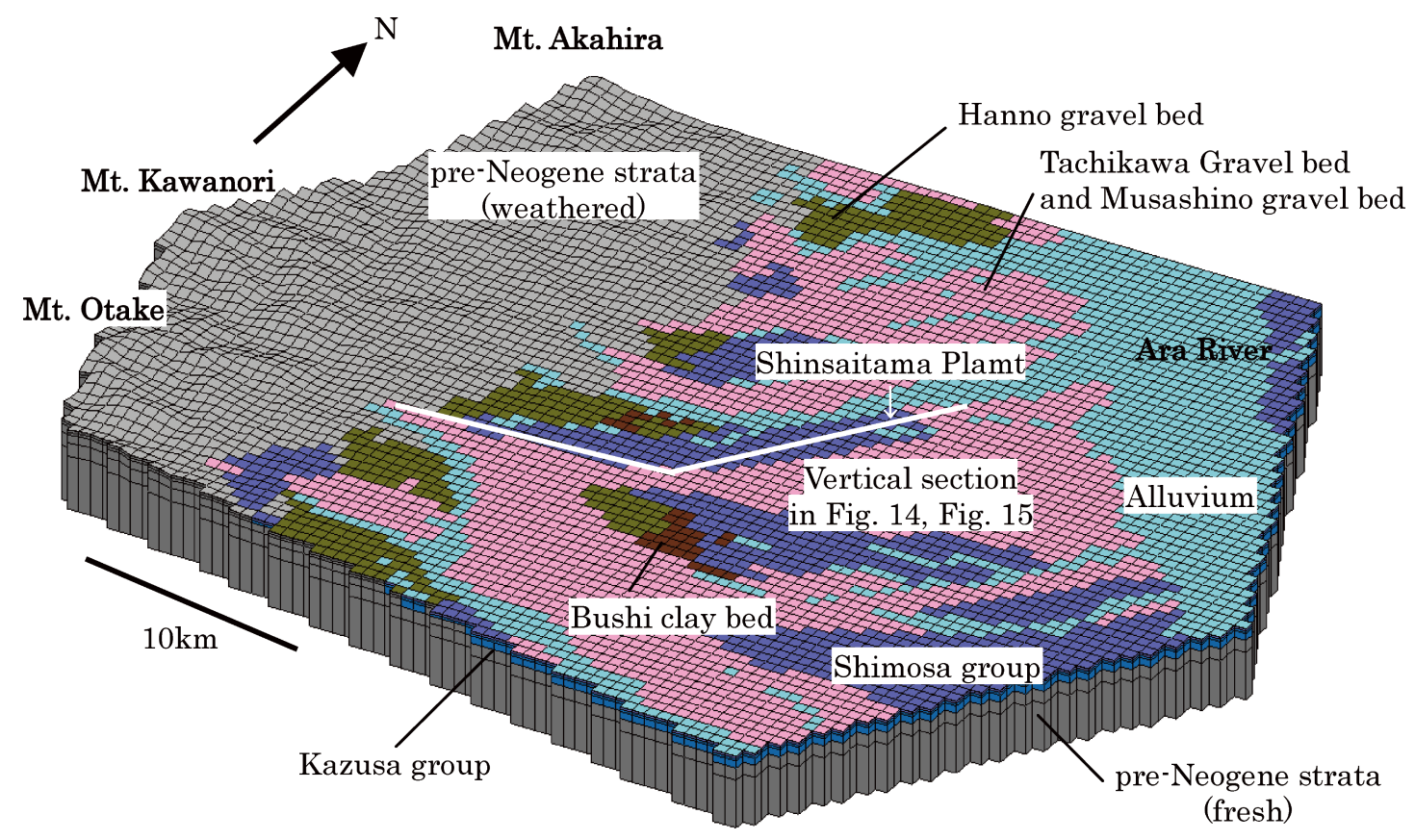

Fig. 10 Simulation model of three-dimensional groundwater flow

Table 3 Basic design for simulation

\begin{tabular}{|c|c|c|}
\hline \multirow{3}{*}{$\begin{array}{l}\text { Boundary } \\
\text { conditions }\end{array}$} & Side and bottom & Impermeable \\
\hline & $\begin{array}{c}\text { Top } \\
\text { (Ground surface) }\end{array}$ & $\begin{array}{c}\text { Infiltration } \\
0.74 \sim 0.96 \mathrm{~mm} \mathrm{~d}^{-1}\end{array}$ \\
\hline & River & Presser head : $0 \mathrm{~m}$ \\
\hline \multirow{2}{*}{$\begin{array}{l}\text { Finite element } \\
\text { method grid }\end{array}$} & Number of elements & 34224 \\
\hline & Number of layers & $\begin{array}{l}6 \text { (minimum thickness } \\
\text { is } 10 \mathrm{~m} \text { ) }\end{array}$ \\
\hline $\begin{array}{l}\text { Method of } \\
\text { analysis }\end{array}$ & \multicolumn{2}{|c|}{$\begin{array}{l}\text { Saturated three-dimensional } \\
\text { seepage analysis }\end{array}$} \\
\hline
\end{tabular}

$-3 \mathrm{~km}$ の範囲である (Fig. 10)。地表面形状の作成に当 たっては国土地理院発行の数值地図により数值標高モデル （DEM）を作成し，DEM を数值モデルの地表面へ貼り付け ることで再現した. 水理地質は第四紀沖積層, 立川・武蔵
野礫層, 下総層群, 仏子粘土層, 飯能礫層, 上総層群及び 先新第三紀堆積岩類に区分した（Table 4). 先新第三紀堆 積岩類については表層レイヤーを風化部とし, 高透水性を 考慮した. 境界条件は地表部のうち河川及び湖沼を定水頭 境界 (圧力水頭 $0 \mathrm{~m}$ ), そのほかを降雨涵養境界とした. 降 雨涵養量は数值モデルをエリア区分し, 数值モデルをエリ ア区分し, AMeDAS 観測点（府中，入間，鳩山）における 年平均降水量と可能蒸発散量及び河川流出率 ${ }^{28)}$ から設定し た.このうち可能蒸発散量については, 2007 年 1 月 31 日 及び 2007 年 5 月 3 日に取得された AVNIR-2 衛星デー夕を 使用し, 正規化植生指数 (NDVI : Normalized Difference Vegetation Index）に基づく土地被覆区分を行い, 土地被覆区 分ごとのアルベドと気象データに基づき算定した（Fig. 11, Fig. 12).

数值モデル側面及び底面は不透水境界とした。プログラ 
ムは計算コードとして 3 次元飽和・不飽和浸透流-移流分 散解析プログラム Dtransu-3D・EL (岡山大学, 三菱マテリ アル，ダイヤコンサルタント共同開発）を使用し，イン ターフェイスについてはプリ/ポストプロセッサーソフト G-TRAN/3D for Dtransu-3D・EL ( ${ }^{\circledR}$ 地層科学研究所) を用 いた. 数值解析の入力条件となる透水係数 $k$ 及び有効間隙 率 $N_{\mathrm{e}}$ は井戸の揚水試験結果や全国の透水係数データ ${ }^{29)}$ 参考に設定した.

\section{$4 \cdot 2$ 解析結果}

解析結果として地下水流跡線を Fig. 13 に, 新埼玉工場を

Table 4 Geology and Property

\begin{tabular}{lcc}
\hline Rock type & $\begin{array}{c}\text { Hydraulic } \\
\text { conductivity } \\
k \times \mathrm{m} \mathrm{s}^{-1}\end{array}$ & $\begin{array}{c}\text { Effective } \\
\text { porosity, } \\
\%\end{array}$ \\
\hline Alluvium & $1.0 \times 10^{-3}$ & 15 \\
Bushi clay bed & $7.3 \times 10^{-9}$ & 15 \\
Hanno gravel bed & $2.0 \times 10^{-3}$ & 15 \\
$\begin{array}{l}\text { Tachikawa gravel bed and } \\
\text { Musashino gravel bed }\end{array}$ & $2.0 \times 10^{-3}$ & 15 \\
$\begin{array}{l}\text { Shimosa group } \\
\text { Kazusa group }\end{array}$ & $7.2 \times 10^{-6}$ & 10 \\
pre-Neogene strata & $1.6 \times 10^{-6}$ & 5 \\
\hline
\end{tabular}

通る東西方向の全水頭断面を Fig. 14 に, 同じく地下水流速 断面を Fig. 15 にそれぞれ示す. 地下水流跡解析では深度の 違いによる地下水起源の差異を評価するため, 井戸のスト レーナー設置深度である GL- $125 \mathrm{~m}$ 及び GL-175 m の 2 深度について，それぞれを終末点とする地下水流動の解析 を行った. 解析の結果, 西方 $14 \sim 16 \mathrm{~km}$ の距離にある入間 川上流域において涵養された地下水が新埼玉工場に向かっ て流下する地下水の流れが予測された．揚水深度の違いが 地下水起源にもたらす差異として, 深度 GL-175 m にお いて汲み上げている地下水は $\mathrm{GL}-125 \mathrm{~m}$ の地下水よりも $2 \mathrm{~km}$ 程度遠方を涵養域とする予測結果となった. 全水頭 断面（Fig. 14）からは涵養域の下流側において GL-800 m 程度まで地下水が浸透し，その後上昇しつつ新埼玉工場へ 向かう流れが再現されている. 計算による地下水のダル シー流速は $0.0005 \sim 0.04 \mathrm{~m} \mathrm{~d}^{-1}$ であり, 有効間隙率 0.15 を 用いて実流速に換算すると $0.003 \sim 0.27 \mathrm{~m} \mathrm{~d}^{-1}$ となる. 以 上の解析により予測された地下水流動は, Fig. 9 に示した 水理概念と整合的であり, 地球化学的手法と数值解析によ る地下水起源判別の可能性が示唆された.

今後の課題として, 涵養量の季節的変化を反映した地下 水流動解析が挙げられる. 我が国では四季により降雨量や 降雪量に差があり，それによって河川流量が増減し，地下 への涵養量も変化することが想定される. 近年, 地形計測 による推定流出率と実測流出率との対比から河川流域ごと の流出率分布を求める手法の研究事例が報告されてい

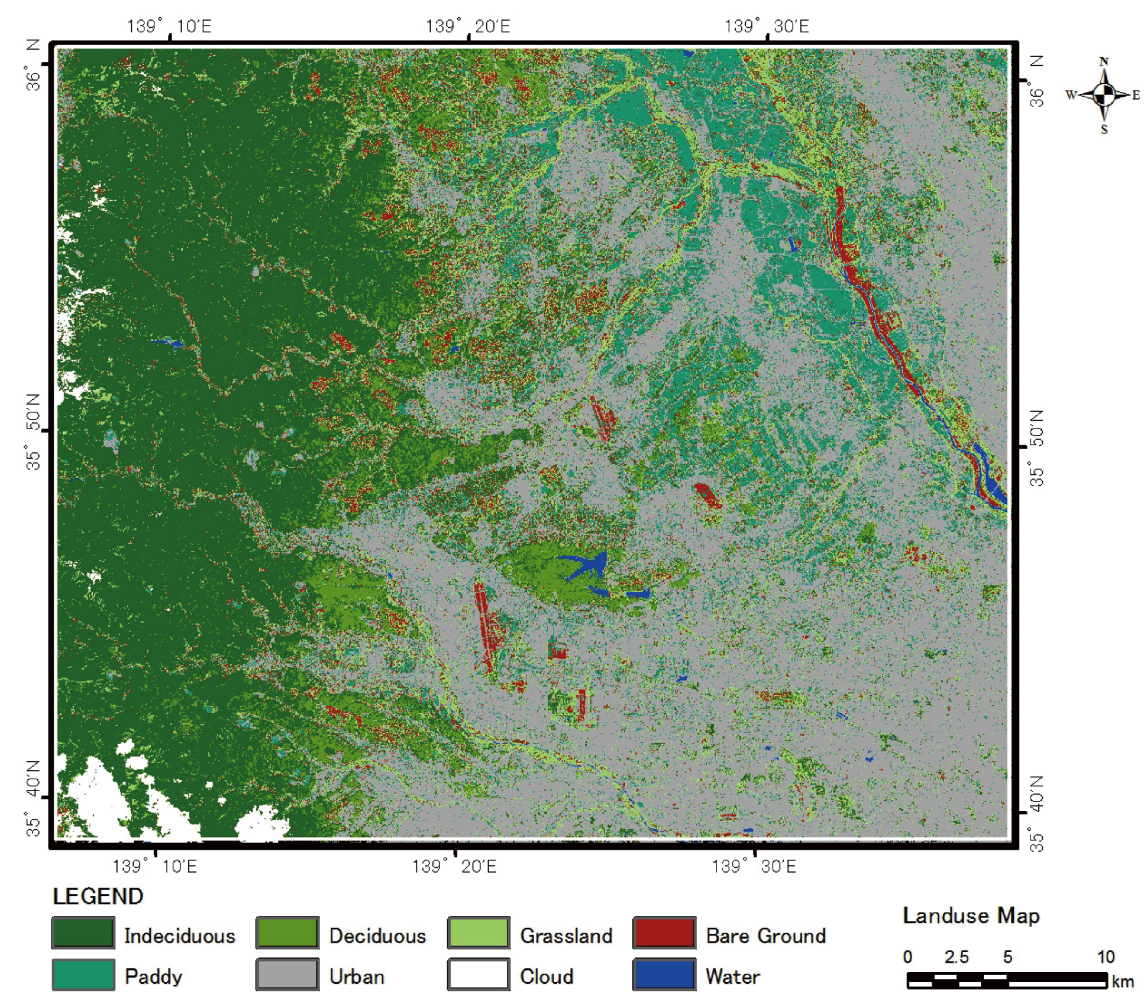

Fig. 11 The land use classification by AVNIR-2 data acquired on 31 $1^{\text {st }}$ January, 2007 and $3^{\text {rd }}$ May, 2007 


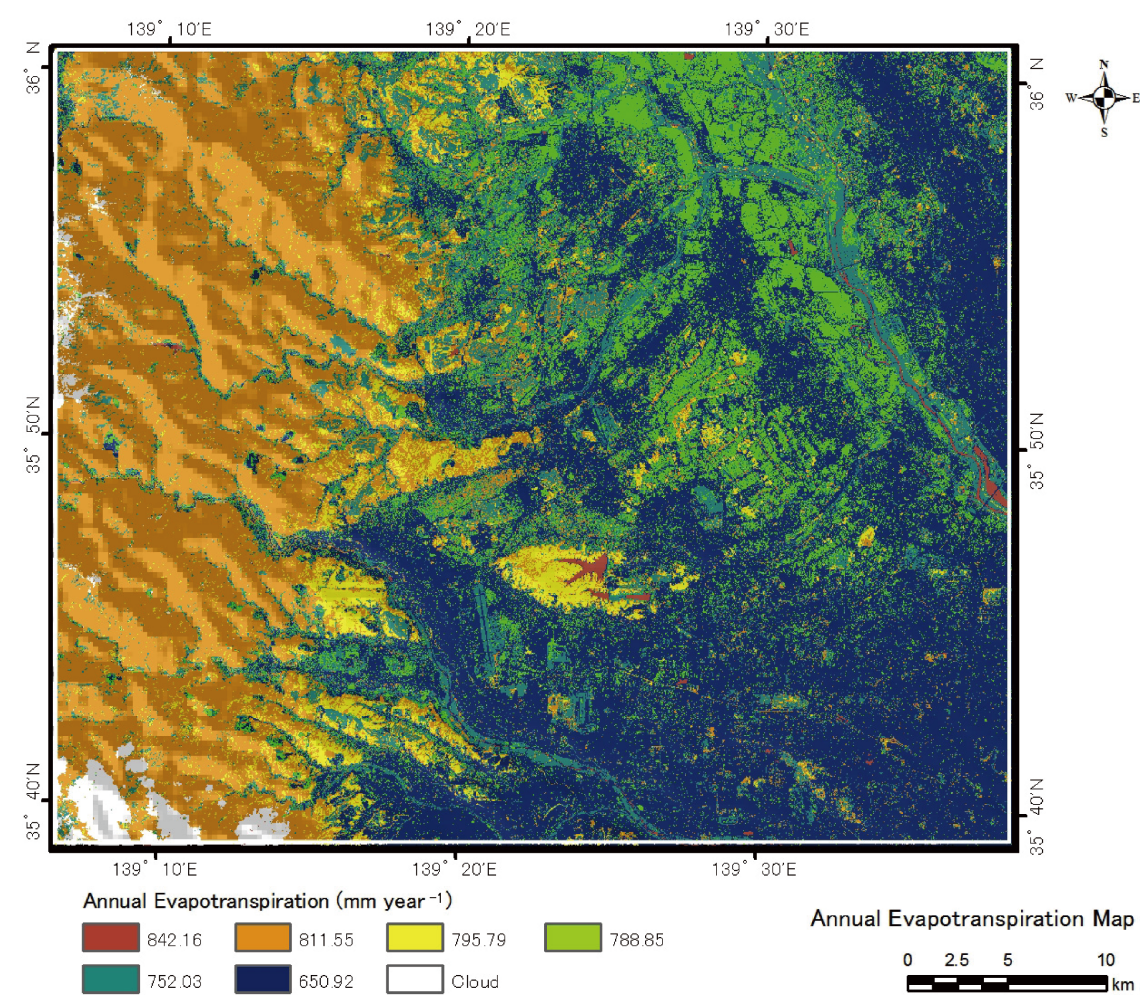

Fig. 12 Annual evapotranspiration estimated by meteorological data and land surface classification

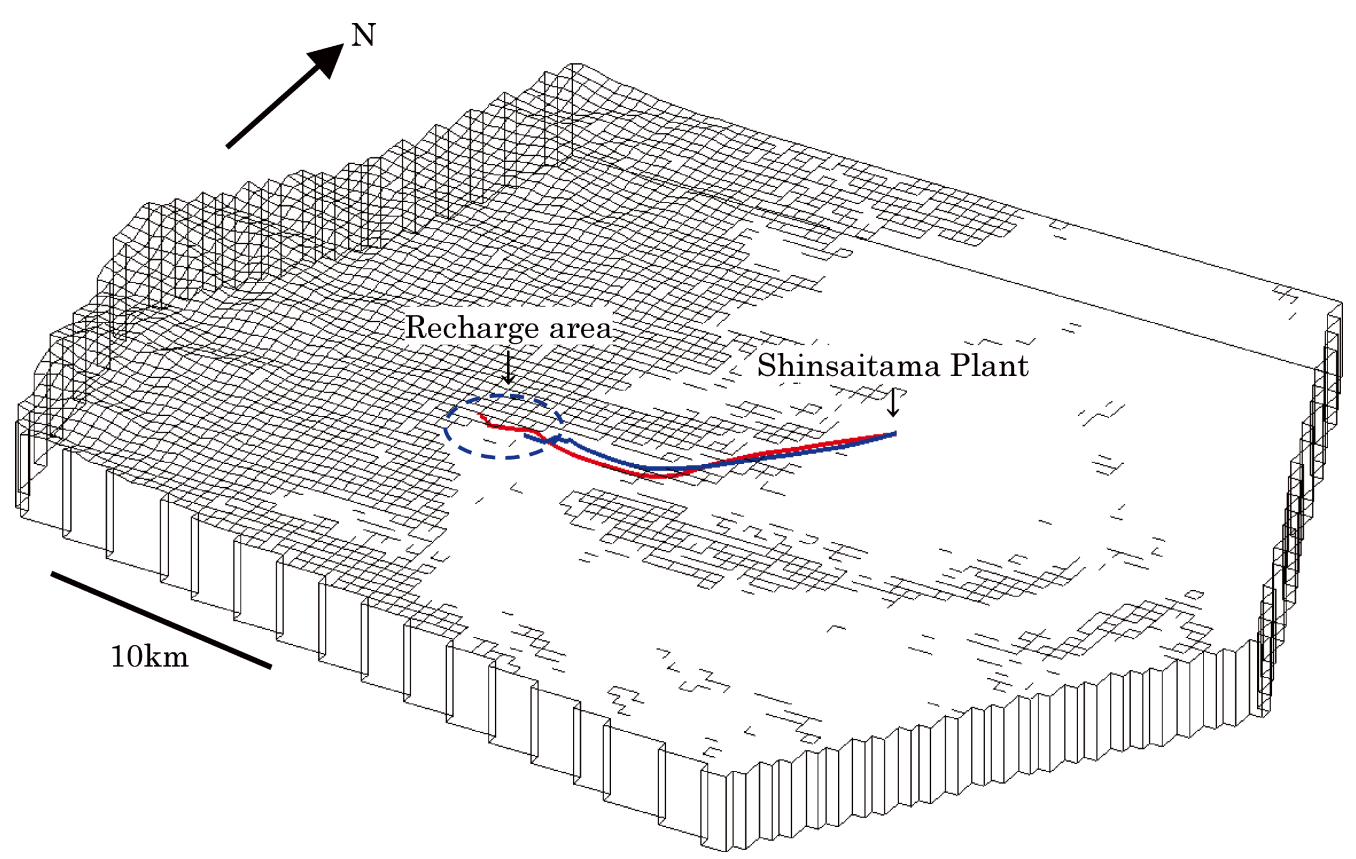

Fig. 13 Stream lines of groundwater toward Shin-Saitama Factory

Red line shows stream line of lower aquifer and blue line shows stream line of upper aquifer

$3^{30)}$. 本手法を適用し涵養量の季節的変化が地下水の起源 や流動へ与える影響を評価することで，地下水源利用に打 ける品質管理の一助になるものと考えられる，今後，更な る検討を進める予定である.
5 結 言

埼玉県狭山市にある新埼玉工場で採水している地下水を 対象に, 主要陽 - 陰イオン濃度や水素・酸素安定同位体比 を用いて起源の推定を試みた。 


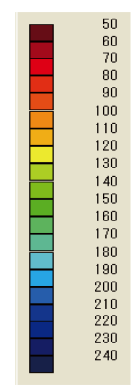

$\mathrm{m}$
W

$$
\begin{aligned}
& \text { E.L. (m) } \\
& 1000-
\end{aligned}
$$

$\leftarrow$
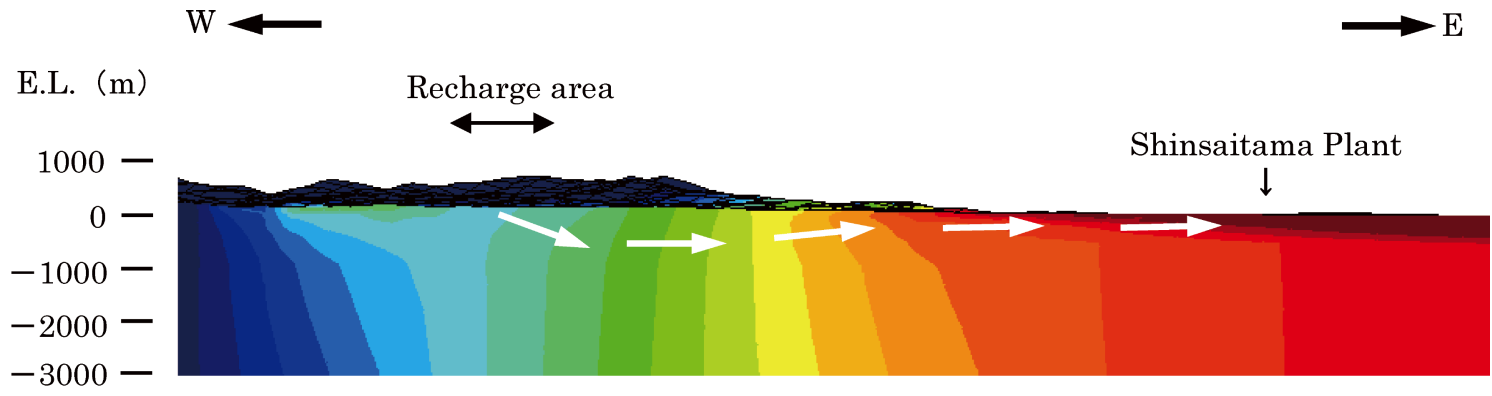

Fig. 14 Distribution of total heads

The white lines show vectors of ground water flow

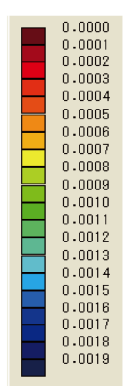

$\mathrm{m} \mathrm{d}^{-1}$

Recharge area
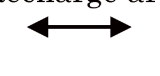

Shinsaitama Plant 
1 土地利用 - 植生状況図 < http://tochi.mlit.go.jp/ tockok/tochimizu/F5/MAP/511002.jpg $>$ (accessed 2010-12-4).

24) 宮下雄二：地下水技術, 48, 25 (2006).

25) 林 武司, 内田洋平, 安原正也, 丸井敦尚, 佐倉保 夫, 宮越昭暢：日本水文科学会誌，33,125 (2003).

26) 宮越昭暢, 内田洋平, 佐倉保夫, 林 武司: 日本水 文科学会誌, 33, 137 (2003).
27) 池田喜代治：ハイドロロジー, 1984, 36 .

28) 風間 聡, 多田 穀, 沢本正樹：水工学論文集, 40, 81 (1996).

29) 梅田浩司, 柳澤孝一, 米田茂夫：地下水学会誌, 37, 69 (1995).

30) 景山宗一郎, 池田 誠, 富山眞吾 : 水文・水資源学 会誌, 23, 301 (2010).

\title{
Estimation of the Sources of Groundwater Used for Food Materials in Sayama City, Saitama Prefecture, by Geochemical Methods and Numerical Simulation
}

\author{
Shingo Tомгунма ${ }^{1}$, Akira $\mathrm{UedA}^{2}$, Akiko KitaI ${ }^{1}$ and Shuichi Aor ${ }^{3}$ \\ ${ }^{1}$ Mitsubishi Materials Techno Corporation, 1-297, Kitabukuro-cho, Omiya-ku, Saitama-shi, Saitama 330-0835 \\ ${ }^{2}$ Graduate School Division of Science and Engineering, University of Toyama, 3190, Gofuku, Toyama-shi, \\ Toyama 930-8555 \\ ${ }^{3}$ Sinsaitama Plant, Foodchemifa Co., Ltd., 1-5-15, Shinsayama, Sayama-shi, Saitama 350-1331
}

(Received 1 September 2010, Accepted 24 December 2010)

Understanding of the source and chemical characteristics of groundwater provides important strategies for the quality management of mineral water and food materials. To identify the source of groundwater used for food materials, water chemistry and stable isotopes of hydrogen and oxygen were examined in well-water from Sayama city, Japan. The well-water samples had similar chemical characteristics to river water in the west-rim of the Kanto plane. The hydrogen and oxygen isotopic ratios of the well-water samples indicated that their origin was solely meteoric, and that the groundwater mainly originated from upstream of the Iruma River (and other rivers) in the west-rim of the Kanto plane. A subsequent groundwater simulation produced down streamlines from the upstream areas of the Iruma River that correspond well with the groundwater flow estimated from the $\delta \mathrm{D}$ and $\delta^{18} \mathrm{O}$ values of the samples. Thus, the stable isotopes and water chemistry of the sampled water, groundwater flow simulation appears to be useful tools for tracing the origin of groundwater used for food materials.

Keywords : Sayama city; groundwater source ; stable isotopic analysis ; groundwater flow simulation. 